\title{
CATULLUS EN KROG: GEBRUIK VAN 'N PERSONA AS METAFOOR VIR DIE KREATIEWE PROSES VAN SKRYF
}

\author{
M Blanckenberg (Universiteit van Stellenbosch)
}

You died two thousand years ago, Catullus, Myriads since then have walked the earth you knew All their long lives and faded into nothing, And still across that waste men think of you.

$$
\text { J C Squire: “To a Roman” (1923)1 }
$$

Hierdie bespreking ondersoek die moontlikheid dat beide Gaius Valerius Catullus en Antjie Krog in hulle digkuns gebruik maak van 'n persona as metafoor vir die kreatiewe proses van skryf.

Gedig c. 50 van Catullus word as voorbeeld gebruik waar die moontlikheid bestudeer word dat die Calvus in gedig c. 50 gebruik word as 'n metafoor vir die kreatiewe proses van skryf. Deur die bestudering van die betrokke gedig word die effek wat Calvus op Catullus uitoefen metafories vergelyk met die effek wat die kreatiewe proses op Catullus uitoefen.

Volgens hierdie lesing van c. 50 konsentreer die digter-persona op sy ervaring van die kreatiewe proses as soortgelyk aan die ervaring van 'n liefdesverhouding. Die studie verken Catullus se gebruik van die Calvus persona in c. 50 as 'n poging van die digter om beide die emosionele en erotiese ervaring van digkuns te verwoord.

In 'n soortgelyke ondersoek word Antjie Krog se gedig "die skryfproses, as sonnet" as 'n voorbeeld van moderne digkuns bespreek, waar (a) die man as metafoor gebruik word vir die proses van kreatiwiteit, en (b) voorbeelde van erotika gebruik word om die ervaring van die kreatiewe proses te verwoord.

Hierdie bespreking van die gedigte van beide 'n antieke en moderne digter plaas die kompleksiteit van Catullus se ervaring van die kreatiewe proses in perspektief ten opsigte van moderne digkuns.

Die gebruik van 'n vrouefiguur as metafoor vir die kreatiewe proses van dig word dikwels aangetref in die poësie van moderne digters, soos Uys Krige se "Poësie" (1964) en D J Opperman se "Poërotica" (1964), terwyl Antjie Krog in haar gedig "die skryfproses, as sonnet" (1981) gebruik maak van die man as metafoor vir die kreatiewe proses. Verder word daar soms 'n blatante vergelyk getref tussen die tipe verhouding wat die skrywer met die proses van dig openbaar teenoor die tipe verhouding wat die skrywer met 'n geliefde mag hê, soos in Joan Hambidge se "Poetic closure" (1997) en Sheila Cussons se "Daad en beskouing" (1983). Ook word die kreatiewe proses heel dikwels as 'n erotiese ervaring beskryf, soos in Pieter van der Lugt se "die selfbevrediging van skryf" (1985), T T Cloete se "loopskrif in 'n vakansiehotel" (1986), Menno Stenvert se "Vers" (1986), Daniel Hugo se "Die besoeker" (1989), Johann de Lange se "Poërotica" (1990) en Joan Hambidge se "Writing as fucking" (1995).

1. Fitzgerald 1995:225. 
Hierdie vergelykings was egter heeltemal ongewoon in Catullus se leeftyd. ${ }^{2}$ As leier van 'n groep moderne digters wat onder hulle tydgenote bekend gestaan het as die poetae novi, ${ }^{3}$ was Catullus 'n bevryder van die Romeinse digkuns soos dit beoefen is voor die Alexandryne. ${ }^{4}$ Die tipe digkuns wat deur Catullus en die ander lede van die groep beoefen is het revolusionêre veranderinge in die Romeinse bewussyn te weeg gebring, wat die latere ontwikkeling van moderne digkuns beïnvloed het. ${ }^{5}$ Die bespreking wat volg fokus op Catullus as een van die eerste digters wat as't ware 'n moderne liefdesverhouding met sy digkuns het. ${ }^{6}$ Groter begrip vir latere digters se ervaring en uitbeelding van die kreatiewe proses van skryf kan moontlik uit hierdie bespreking ontwikkel.

Hierdie bespreking ondersoek Catullus se metaforiese gebruik van die Calvus-persona om die kreatiewe proses in die vorm van 'n liefdesgedig ${ }^{7}$ uit te beeld. Die moontlikheid word ondersoek dat die Calvus in Catullus se gedigte as 'n metafoor dien vir die kreatiewe proses van skryf. Sodoende word 'n geleentheid geskep om die proses van dig beter te begryp, wat die tydloosheid van Catullus se invloed op digkuns bevestig.

Netso word die moderne Afrikaanse gedig "die skryfproses, as sonnet" van Antjie Krog ook ondersoek as 'n gedig waar Krog se gebruik van die man as persona binne die ontwikkeling van die metafoor vir skryf vertoon word. Verder dra haar gebruik van erotiese taal by tot die uitbeelding van die seksuele ervaring van die kreatiewe proses van skryf.

C. 50 vertoon Catullus se ervaring van die kreatiewe proses die sterkste. In hierdie gedig word die Calvus-persona metafories gebruik om die kreatiewe proses van skryf uit te beeld as soortgelyk aan 'n liefdesverhouding. Die ontwikkeling van die metafoor geskied deur Catullus se gebruik van erotiese taal en sy beskrywing van die psigologiese en fisiologiese effek wat die kreatiewe proses meebring.

2. "Catullus entered Latin poetry as a voice not at all like those that the ears of his fellow citizens were used to hearing ... and so, when his first audience discovered Catullus among the neoterics, he must have been as much of a shock to his fellow citizens as the early twentieth-century modernists were to ours" (Martin 1990:ix).

3. Ook anders bekend as die "neoterics".

4. "Inspired by the classical postmodernism of Alexandrian poetry, a group of poets known today as the neoterics were writing poems that were playfully cerebral, sophisticated in their sensuality, and emphatically subjective. Nothing like this had happened to Latin verse before this happened to it" (Martin 1990: $x$ ); "[t]his is poetry so new in Latin, we may legitimately speak of revolution" (Quinn 1972:20).

5. "Many centuries before the advent of the poets of romantic love, Catullus foreshadowed the ideal to which they, and the Western European world after them, at least in theory subscribed" (Copley 1949:40).

6. "Catullus reverses the relationship between man and woman that is taken for granted by his Hellenistic predecessors" (Rubino 1975:295). Ook Arkins (1982:1) lewer kommentaar oor Catullus se hantering van seksuele temas: “. . . it is Catullus' treatment of sexual themes which makes him particularly significant in a post-Freudian era and shows him anticipating many modern attitudes".

7. C. 50 word nie algemeen aanvaar as 'n liefdesgedig nie: Kritici soos Segal (1970:25-31), Williams (1980:214) en Newman (1990:127-8) bespreek c. 50 as 'n liefdesgedig vir digkuns, teen kritici soos Fraenkel (1956:278-282), Scott (1969:169-172) en Williams (1988:69-73) wat c. 50 in die eerste plek nie as 'n liefdesgedig beskou nie, maar eerder ' $n$ vriendskapsgedig. 
L (Lee, 1990:48)

Hesterno, Licini, die otiosi multum lusimus in meis tabellis, ut convenerat esse delicatos: scribens versiculos uterque nostrum ludebat numero modo hoc modo illoc, reddens mutua per iocum atque vinum. Atque illinc abii tuo lepore incensus, Licini, facetiisque, ut nec me miserum cibus iuvaret nec somnus tegeret quiete ocellos, sed toto indomitus furore lecto versarer, cupiens videre lucem, ut te cum loquerer simulque ut essem. At defessa labore membra postquam semimortua lectulo iacebant, hoc, iucunde, tibi poema feci, ex quo perspiceres meum dolorem. Nunc audax cave sis, precesque nostras, oramus, cave despuas, ocelle, ne poenas Nemesis reposcat a te; est vemens dea: laedere hanc caveto.

\section{50 (Outeur se vertaling)}

Gister, Licinius, het ons fees gevier en menigte speletjies met my skryfplankies gespeel, want ons het ooreengekom om pret te hê.

Beide van ons was gestimuleer deur versskrywing, eers in een metrum, dan in 'n ander, terwyl ons mekaar beantwoord, gelag en wyn gedrink het Ek het daar weggestap so opgevlam deur jou spitsvondigheid en prettigheid, Licinius, dat kos nie my pyn kon stil, nog slaap my oë kon ontspan nie, rusteloos en koorsig het ek rondgerol in my bed, verlangend uitgesien na die sonsopkoms dat ek met jou kan praat en by jou kan wees. Maar toe my ledemate verswelg was met moegheid en ek half dood op die rusbank lê, het ek hierdie gedig vir jou gemaak, my liewe vriend, dat jy daaruit van my lyding sal weet. Moet nou nie te trots wees nie, en moenie, ek smeek jou, appel van my oog, my gebede verwerp nie, want Nemesis kan dalk 'n strafgeding teen jou aanvra 20 as terugbetaling.

Sy is 'n heersugtige godin, wees versigtig om haar nie te beledig nie.

Die meeste kommentatore is dit eens dat Catullus gebruik maak van 'n passievolle woordeskat en hanteer c. 50 deur eers die letterlikheid van hierdie woorde te bevraagteken, waarna 'n poging aangewend word om 'n motivering vir Catullus se gebruik daarvan te verskaf. Alhoewel sommige van hierdie standpunte opponerend van aard is, lewer kritici meestal net 'n klemverskil in hul motivering vir Catullus se gebruik van seksueel suggestiewe woorde en beelde.

Onder die tweede groep wat c. 50 wel as 'n liefdesgedig ${ }^{8}$ beskou, is die belangrikste bespreking dié van c. 50 as 'n uitbeelding van 'n verband (metafoor) tussen tema (Catullus se verhouding met Calvus) en komposisie (die kreatiewe proses). Quinn (1972:280) beskryf c. 50 as die gedig wat Catullus se eerste bewussyn van sy erns vir digkuns illustreer. ${ }^{9}$

Hierdie intense gevoel wat Catullus vir digkuns openbaar word reeds in 1939 deur Havelock vergelyk met 'n persoonlike verhouding: "Literature was an activity for him like a personal relationship, and had the same exciting quality. The same charm, the same taste, were the touchstones of friendship, of poetry and of love" (1939:114).

In die konteks van c. 50 verbind Williams (1980:214) Catullus se uitbeelding van sy verhouding met Calvus met die tema van poëtiese komposisie en kompetisie: "In its language the main field of the poem seems to be that of homosexual passion, but the opening lines,

8. Daar is wel kritici soos Clack (1976:50-53) wat reken c. 50 is inderwaarheid 'n erkenning van Catullus se gevoel teenoor Clodia.

9. "Poem 50, I suspect, puts on record Catullus' own understanding of how it all began; it is, so to speak, his expression of his own awareness of the point at which playing with verse ceased to be just an amusing pastime" (Quinn 1972:280). 
which prepare for that field, also contain an index of proportionality to another field - that of the composition of poetry"

Williams noem dat alhoewel die aard van die inspirasie vir poëtiese komposisie nie direk genoem word nie, daar gesuggereer word dat die onderwerp eroties is, deur die gebruik van woorde soos lusimus (v. 2), delicatos (v. 3), versiculos (v. 4) en ludebat (v. 5): "The reader is left to reconstruct the field of poetic composition ${ }^{11}$ by sensing its proportionality with the field of physical passion" (1980:214). Volgens Williams word c. 50 geïnspireer deur die homoseksuele aard van die verhouding tussen Catullus en Calvus, wat hy ondervind gedurende die skryf van gedigte: "This actual poem itself exemplifies what it is talking about, and it carries within it the generation of its own inspiration" (1980:214).

Arkins (1982:30-31) se bespreking van c. 50 as 'n uitvloeisel van die gees waarin Catullus geleef het, sluit aan by Williams se siening, in die sin dat Arkins Catullus se ervaring van sensualiteit en die skryf van poësie as interaktief beskou. Arkins reken dat dit onnodig is om beperkinge op die gedig, of Catullus se verhouding met Calvus te stel: "It is not necessary to posit a homosexual relationship between Catullus and Calvus or to regard all this as parody in order to read the poem correctly: given the intensity of Catullus' devotion to poetry, his great friendship with Calvus and his preoccupation with sexual themes, it is entirely understandable that this writing of risqué verse should induce in him a quasi-sexual longing for Calvus which is couched in sexual images and language; for Catullus such a mode of expression is what the French call une manière d'être" (1982:30-31).

Segal (1970:27) gee 'n soortgelyke beskrywing van Catullus se ervaring van digkuns: "The amatory language reveals a man who feels for his literary experience as something sensual. For Catullus the life of art has an intensity which approaches the life of passion. Art and sensual passion become, in this case, virtually inextricable." Hy noem dat hierdie versmelting van literêre belang en sensuele passie vasgevang word in die woord otiosi (v. 1), en bou sy argument rondom dié woord deur ook na die gebruik daarvan in ander gedigte van Catullus en ander skrywers te verwys: "It is otium which bridges both sides, unites love and poetry, for otium is indispensable to both; and it is 50 which brings home that connection in the characteristically subtle, anecdotal, understated, and ostensibly 'nugatory' manner of the novi poetae and their Hellenistic predecessors" (1970:28).

Volgens Newman (1990:127) word die graad van Catullus se erns teenoor digkuns openbaar deur sy gebruik van die taal van die liefde: "This is the vocabulary of love ... and indeed we have to deduce from the psychology they reveal the degree of commitment to his vocation felt by the poet." Hy verduidelik dat c. 50 Catullus as digter en sy passie vir digkuns uitbeeld: "This passion, directed not towards some girl, but to poetry and even to the goddess Nemesis, is not therefore random and diffuse emotion. Catullus as a writer embodies his feelings in words. He makes (procreates) something (hoc, iucunde, tibi poema feci ${ }^{12}$ ), and this

10. Outeur se beklemtoning: dit is hierdie tweede vlak in die gedig se betekenis wat vir die bespreking veral van belang is.

11. Outeur se beklemtoning: die leser moet self die verband lê tussen die eerste en tweede betekenisvlakke van die gedig. Catullus maak gebruik van die eerste betekenisvlak om die tweede indirek te beskryf: Sy ervaring van die kreatiewe proses is soortgelyk aan sy ervaring van 'n liefdesverhouding. Die uitbeelding van sy verhouding met Calvus (die eerste betekenisvlak) staan dus as 'n metafoor vir sy verhouding met digkuns, oftewel die kreatiewe proses.

12. V. 16. 
something he immediately submits to the judgement of his poet-friend, fearful, as he pretends at least, of the outcome" (1990:127-8). ${ }^{13}$

Vanuit die voorafgaande sekondêre bronbespreking kan opsommend verwys word na c. 50 as 'n gedig wat, alhoewel dit nie algemeen aanvaar word as 'n liefdesgedig nie, tog geïnterpreteer kan word as 'n liefdesgedig vir digkuns. Deur nabye bestudering van c. 50 se twee betekenisvlakke, soos duidelik uiteengesit in die bespreking van Williams (1980:214), ${ }^{14}$, is dit moontlik om die eerste betekenisvlak te identifiseer as ' $\mathrm{n}$ metafoor vir die tweede. Catullus ervaar die proses van skryf soos 'n liefdesverhouding, en sy uitbeelding van sy vriendskap met Calvus word 'n metafoor vir sy verhouding met die digkuns, of die kreatiewe proses. Catullus se gebruik van erotiese woorde het dus indirek ten doel om die tipe ervaring weer te gee wat deur hom ondervind word gedurende die skryf van gedigte. Vervolgens fokus die outeur op 'n gedetaileerde analise van c. 50 waardeur hierdie siening van die funksie van die erotiek in die gedig voorgestel word.

Catullus maak gebruik van die Calvus-persona om 'n tweevlakkige boodskap oor te dra. Op 'n eerste vlak is c. 50 bloot 'n gedig aan 'n vriend en mede-digter waar hy deur die skryf van die gedig vra om 'n verdere ontmoeting, gesien die feit dat hulle so 'n aangename tyd deurgebring het met sy skryftablette. Op 'n tweede vlak suggereer Catullus dat die intensiteit van die stimulasie van die kreatiewe proses ooreenkom met dié van 'n seksuele ervaring, en dat wanneer Calvus afwesig is, hy simptome ervaar soortgelyk aan die van 'n verlate minnaar in 'n liefdesverhouding. Catullus vergelyk dus sy ervaring van die kreatiewe proses, soos gedeel met Calvus, met 'n seksuele ervaring, en mak van c. 50 'n liefdesgedig vir die digkuns, gerig aan Calvus. Sodoende val die klem nie meer op Calvus nie, maar op die digkuns en uiteindelik die kreatiewe proses.

C. 50 bestaan uit vier sinne wat elk rondom 'n vokatief gerangskik is, en die gedig vierdelig verdeel. ${ }^{15}$ Die laaste twee sinne kan egter saam ingedeel word sodat ons volgens onderwerp drie hoofdele identifiseer, naamlik A1 (vv. 1-6), B (vv. 7-13) en A2 (vv. 14-21) wat onderskeidelik bestaan uit 6, 7 en 8 versreëls. Die A2 afdeling sou verder verdeel kon word in twee sub-afdelings A2.1 (vv. 14-17) en A2.2 (vv. 18-21) wat onderskeidelik bestaan uit een sin van vier versreëls.

Afdeling A1 vertel die leser van die vorige dag se gebeure waar Catullus en Calvus saam die dag geniet het. In afdeling B word Catullus alleen voorgestel terwyl hy nadink oor die dag en die leser sy reaksie op die gebeure waarneem. Afdeling A2 volg logies op die B Afdeling waar Catullus 'n verduideliking vir die skryf van die gedig in A2.1 verskaf en in afdeling A2.2 vra om 'n verdere ontmoeting. Om op te som: Afdeling A1 stel Catullus en Calvus saam voor in die verlede, afdeling B stel Catullus alleen voor en afdeling A2 vra dat hul verenig sal

13. Burgess sluit Catullus se ervaring van poësie by sy beskrywing in: "Recent scholars have understood that the erotic language in lines 7-21 is used to give weight to an intellectual and poetic experience, rather than to express genuine erotic feelings" (1986:584). In sy artikel fokus Burgess egter op die reëls van die spel van gedigsuitruiling waarby Catullus en Calvus oënskynlik betrokke was, en beskou hy eerder die gebruik van erotiese taal as 'n versoek om 'n voortgesette literêre spel: "The request for erotic favor becomes a request for poetry in what is now understood to be an ongoing game of reciprocal composition which includes this very poem...C. 50, a request for poetry, contains erotic language in order to specify the request, as well as to amplify obligations placed on Calvus" (1986:586).

14. Verwys na p.48.

15. Die vier vokatiewe is Licini (v. 1) wat herhaal word in v. 8, iucunde (v. 16) en ocelle (v. 19). Al vier woorde spreek Calvus aan en versterk sodoende sy sentrale posisie in die gedig. 
wees in die toekoms. Die breë struktuur van die gedig (A1-B-A2) word ten volle ondersteun deur die interne struktuur van die individuele afdelings, wat as volg geïlustreer word:

Die openingsreël van afdeling A1 (v. 1) word in drie duidelike dele verdeel deur twee kommas. Sodoende word die leser gedwing om die woorde stadig uit te spreek en word aandag beurtelings gevestig op die drie belangrike woorde: Hesterno, Licini en otiosi. ('n Soortgelyke verdeling word aangetref in vv. 8, 16 en 18 wat later bespreek sal word). Hesterno (v. 1) plaas die gedig onmiddellik in 'n bepaalde verlede tyd wat die leser inlig dat daar oor iets geskryf word wat reeds gebeur het. Dié sterk woord trek onmiddellik die leser se aandag en bou dramatiese spanning aangesien die leser wonder wat belangrik is omtrent die genoemde dag. ${ }^{16}$ Die tweede woord Licini (v. 1) spreek Calvus aan en stel hom terselfdertyd voor aan die leser. Sodoende rig Catullus c. 50 aan beide Calvus en die leser: 'n bydrae tot die beskouing van c. 50 as beide 'n private en publieke gedig. ${ }^{17}$ Die plasing van Licini tussen die woorde Hesterno...die (v. 1) skep 'n A-B-A struktuur binne die eerste versreël waar Calvus in die middel van die vorige dag se gebeure geplaas word. Hiermee verseker Catullus die interpretasie van die gedig se eerste vlak waar Calvus die middelpunt van die dag se gebeure vorm. Otiosi aan die einde van v. 1 speel net so 'n belangrike rol soos Hesterno en Licini, aangesien dié woord die gemaklike, spelerige en seksueel suggestiewe stemming van die gedig inlei, wat verder ontwikkel word in afdeling A1. ${ }^{18}$

In vv. 2-6 brei Catullus uit oor die gebeure wat die vorige dag plaasgevind het en word die leser sodoende ingelig. Catullus en Calvus het baie pret met sy tabellis gehad (v. 2). ${ }^{19}$ Die volrondheid van multum lusimus (v. 2) bevorder die sensuele stemming soos ingelei deur otiosi (v. 1). Die dubbele gebruik van ludere as lusimus (v. 2) en ludebat (v. 5) beklemtoon die spelerige aard van beide hul saamwees en die aard van die gedig. Ook beskik ludere oor seksuele konnotasies wat ná otiosi (v. 1) aan die gedig 'n sterker sensuele inslag verleen. ${ }^{20}$

16. Volgens Quinn (1973:237) help die gebruik van die woord hesterno om 'n sterk opening te bou en is dus meer effektief as die meer informele heri. Alhoewel Ellis (1889:172) hesterno as "rather more formal than heri" beskryf, noem Fordyce (1961:215) dat hesterno wel voorkom in 'n informele gesprek tussen karakters van Petronius $(131.2,139.5)$.

17. Quinn (1959:87-88) verduidelik dat die poetae novi dikwels die tradisioneel sentrale posisie van die publieke gehoor (as die digter se oogmerk in die skryf van gedigte) geïgnoreer het. Nieteenstaande is daar genoeg bewyse dat c. 50 wel vir beide Calvus en die leser geskryf is. Volgens Quinn (1973:237) is c. 50 duidelik verander met die oog op publikasie: "Lines 1-6 tell the reader what he needs to know — one sign that this apparantly spontaneous poem has been carefully rearranged for publication". Ook Fordyce (1961:215) lewer kommentaar hieroor: "The lines are 'To Calvus', but Calvus did not need to be told what he had been doing the night before; Catullus is writing for other readers." Ferguson (1985:143): "we are made to feel that the curtain has been drawn aside from a private event and we are privileged spectators. It $i s$ a private poem; it is also a public poem."

18. Fordyce (1961:215) vertaal otiosi as "having nothing to do." Hierdie vertaling laat nie reg geskied aan die gebruik van otiosi by c.50 nie, soos beaam deur Quinn (1973:237) waar hy noem dat otiosi by Catullus geïnterpreteer moet word as "time spent enjoying oneself" eerder as "relaxing, or doing nothing"; cf. 51. 1316. Sien Segal (1970:25-31) vir die verband tussen otium en digkuns, asook Laidlaw (1968:41-52) vir 'n skerpsinnige en beredeneerde conspectus van die woord otium en sy verskeie betekenisse.

19. Volgens Quinn (1973:237) kan meis in meis tabellis (v. 2) verwys na die skryftablette wat Catullus op daardie oomblik vir c. 50 gebruik. Quinn verwys na Propertius 3.23 vir die gebruik van tabellae gedurende 'n briewewisseling.

20. Ellis (1889:172) verskaf die beste vertaling vir die woord lusimus as "indulged our fancy." Sy vertaling verleen 'n toepaslike dubbelsinnigheid aan die woorde wat die waarneem van seksuele ondertone versterk. Ellis noem slegs lusimus se betekenis ten opsigte van die improvisasie van ligte verse en verwys na 61. 225 Lusimus satis en 'n fragment van Varro se Tithonus, v. Riese (Non. 343) Risi multum, lusi modice iambis. Merrill (1951:83) noem dat lusimus dui op liriese, en veral liefdesvers komposisies en verskaf voorbeelde: 
Catullus en Calvus het ooreengekom om delicatos te wees (v. 3). Convenerat (v. 3) dui op die feit dat hulle besluit het om bymekaar te kom en delicatos (v. 3) dat hulle besluit het om hulself te geniet. $^{21}$ Beide woorde beskik oor seksuele konnotasies en die kombinasie van convenerat en delicatos verterk die seksuele aard van die beskrywing tot so 'n mate dat daar al gespekuleer is oor die moontlike seksuele aard van Catullus en Calvus se verhouding. Tog maak die aard van hul spel nie 'n verskil aan die boodskap nie. Die outeur is van mening dat bogenoemde woorde spelerig gebruik word en eerder bydra tot die ontwikkeling van Catullus se voorstelling van die kreatiewe proses as 'n intense erotiese ervaring.

Verder het hulle afwisselend versiculos (v. 4) in verskeie metrums spelenderwys geskryf (v. 5). Versiculos is kort verse, nie ernstige gedigte nie, en word geskryf met die doel om te vermaak. Dit is heel dikwels eroties en soms homoseksueel van aard (cf. c. 16, 3). ${ }^{22}$ Die gebruik van die verkleiningsvorme tabellis (v. 2) en versiculos (v. 4) beklemtoon die feit dat hulle nie ernstige poësie geskryf het nie. ${ }^{23}$ Verder het hulle grappies gemaak en daarop gedrink (v. 6). Die woord mиtua (v. 6) beklemtoon die vriendskapsband wat tussen hulle gevorm het. ${ }^{24}$

Die spelerige, seksueel suggestiewe stemming wat in afdeling A1 (vv. 1-6) gevestig word deur woorde soos otiosi, ludere, convenerat, delicati en versiculos skep 'n atmosfeer wat die aard van Catullus en Calvus se luim die vorige dag weerspieël en berei ons voor vir die sterker seksuele beelde in die B afdeling (vv. 7-13).

cf. 61. 232; 68. 17; Hor. Carm. I. 32. 1; Verg. Ecl. I. 10; Aus. Epist. 7. 1. Fordyce (1961:215-6) noem ook dat die gebruik van ludere en lusus vir die skryf van ligter versvorme later ontwikkel het. Fordyce vertaal beide vorme as "we amused ourselves", wat in die konteks van c. 50 'n beter opsie bied as Quinn (1973:237) se vertaling van lusimus (v. 2) as "had a good time," en ludebat (v. 5) as "made jokes."

21. Volgens Ferguson (1985:143) word die woord convenerat dubbelsinnig gebruik: "It points to the fact that they have come together. It means that they had mutually agreed to put on this character for the day; it also means that it was appropriate for them to spend the day like that, being what they were." Om te reageer op Ferguson se stelling "being what they were" kan Fordyce (1961:216) se vertaling van convenerat esse delicatos aangehaal word: "we had agreed to be naughty." Fordyce bespreek verder die verband tussen deliciae en delicatus. Volgens Fordyce is die basiese begrip van deliciae "allurement" en word die woord op die eenvoudigste manier gebruik as "pet" of "darling." "The relation between deliciae and delicatus is obscure and it may well be that the words have entirely different origins; ...delicatus was treated as the adjective corresponding to the noun deliciae. Between them the words cover the whole range of uninhibited behaviour from wilfulness, caprice, egoism, airs, fads and affections, dandyism, to irresponsible pleasureseeking, frivolity, dissipation, and sensuality." Fordyce (1961:216-7) verduidelik verder dat Cicero, as 'n moralis, die woorde deliciae en delicatus gebruik om die morele onverantwoordelikheid van die boheemse gemeenskap uit te druk: "In Cael. 19 Cicero quotes the word deliciae with obvious distate," maar vir Catullus was daar geen rede om verleë te wees oor deliciae nie: "for Catullus and Calvus delicati versus are something of which they make no secret - irresponsible naughtiness is life to them."

22. Quinn (1973:237-8) vertaal versiculos as "scraps of verse, epigrams." Volgens Quinn dui versiculos op die graad van erns en die lengte van die individuele komposisies, en nie die versreëllengtes nie. "Catullus and Calvus were not writing poetry, but vers de société." Hy noem dat die epigram c. 113 oor Pompeius die een oorblywende voorbeeld van versiculi deur Calvus is, "with indecent undertones." Ellis (1889:172) verwys na Horatius wat sy Epodes (cf. Epod. xi. 2) versiculi genoem het, asook die gedigte wat hy in Grieks begin skryf het (S. i. 10. 32) en versreëls wat 'n erotiese epigram van Callimachus naboots (S. i. 2. 109).

23. Ferguson (1985:143) lewer kommentaar oor Catullus se gebruik van verkleiningsvorme: "This is not serious poetry for which Catullus uses canere or exprimere; the use of diminutives at tabellis and versiculos reinforces the point."

24. Fordyce (1961:217) vertaal reddens mutua (v. 6) as "giving and taking" waar Catullus en Calvus oor en weer verse geskryf het. Quinn (1973:238) beskryf reddens mutua as “a process of capping one another's lines - i.e. short epigrams." 
In afdeling B deel Catullus mee dat hy, nadat hy Calvus agtergelaat het, in 'n toestand van opgewondenheid verkeer het wat aangevuur is deur Calvus se sjarme en spitsvondigheid (vv. 7-8). Waar Licini vroeër in die middel van die vorige dag geplaas is (Hesterno...die, v. 1), bevind hy homself in v. 8 tussen 'n emosionele ervaring (incensus, v. 8) en 'n karaktereienskap (facetiisque, v. 8). Sodoende word die verhoogde intensiteit van Catullus se ervaring van die kreatiewe proses saam met Calvus topografies uitgebeeld.

Catullus was vroeër saam met Calvus otiosi (v. 1) en het saam multum lusimus (v. 2). Nou is hy egter incensus (v. 8) en het geen eetlus meer nie (v. 9). Hy is slapeloos (v. 10) en rol furore rond (v. 11) terwyl hy wag vir die volgende dag (v. 12) sodat hy Calvus weer kan sien en met hom kan praat (v. 13). Die woorde miserum, furore en cupiens (v. 13) word geassosieer met liefdestaal en bogenoemde beelde toon dat Catullus simptome ondervind wat tipies geassosieer word met verliefdheid. ${ }^{25}$ Dié gebruik van sterker seksuele beelde en liefdeswoorde in afdeling B veroorsaak 'n stelselmatige opwerk na 'n hoogtepunt (v. 13) wat vergelyk kan word met 'n seksuele klimaks.

Hierdie klimaks word gevolg deur 'n anti-klimaks in afdeling A2.1 (vv. 14-16) waar Catullus in 'n semimortua toestand uiting gee aan sy frustrasie, deur die skryf van c. $50 .{ }^{26}$ In v. 16 word Licini (soos gevind in v. 1 en 8) vervang met iucunde. Alhoewel iucunde op 'n meer intieme vlak na Calvus verwys, is die noem van sy naam nie so prominent soos Licini in versreëls 1 en 8 nie. Waar iucunde 'n fokuspunt gerig op Calvus is, vorm tibi poema feci (v. 16) 'n tweede fokuspunt wat die skryf van c. 50 beklemtoon. Die feit dat die sinsnede tibi poema feci langs iucunde in dieselfde versreël staan (v. 16), bevestig die belang van beide Calvus en die kreatiewe proses, en hulle word gelyk gestel aan mekaar.

In A2.2 (vv. 17-21) dreig Catullus vir Calvus spelenderwys met die toorn van die godin Nemesis, indien Calvus nie ag slaan op sy versoek om 'n volgende ontmoeting nie (vv. 1820). ${ }^{27}$ Hierdie versoek word nie in formele terme gestel nie, maar Catullus maak eerder gebruik van 'n skoorsoekerige, skertsende toon. Die keuse van hierdie inslag is bloot ter wille van selfbeskerming, aangesien daar 'n moontlikheid bestaan dat Calvus nie belangstel in 'n nabye vriendskap nie (Quinn, 1973:239) ${ }^{28}$ Die ligte, speelse toon wat in A1 gevestig is, word hier hervat en dra verder by tot die breë struktuur van die gedig (A-B-A).

Catullus gebruik eroties-assosiatiewe woorde in afdeling A1 en sterk seksuele beelde in afdeling $\mathrm{B}$ om aan te dui dat sy erns ten opsigte van digkuns, asook die intensiteit van die

25. Fordyce (1961:217) lewer die volgende kommentaar ten opsigte van Catullus se gebruik van hierdie woorde: "The words [incensus en dolor] are those which represent a lover's emotions - desire and heartache...Catullus finds in these an analogy to his own feelings for the object of his admiration." Ook Ferguson (1985:144) verskaf sy opinie in verband met Catullus se gebruik van liefdestaal: “...it would, I think, be a mistake to analyse this in terms of homosexual attraction, and to suggest that the vocabulary is governed by the fact that they were improvising love-poetry is to trivialize it. Rather it represents the fact that creative writing gives Catullus an almost sensual satisfaction — as a shared experience."

26. Volgens Quinn (1973:239) gebruik Catullus by geleentheid (c. 7. 1) rare veellettergrepige woorde. Hy stel voor dat Catullus die woord semimortua vir die gedig geskep het. Ook Fordyce (1961:218) noem dat die gebruik van "semimortua" vir die eerste keer in c. 50 opgemerk is, en eers weer daarna in Apuleius.

27. Volgens Merrill (1951:84) verskyn die godin Nemesis ook as die wreker van dié wat die liefde minag (Ovidius. Met. III. 406 ff.). Ferguson (1985:144) reken dat die gebruik van Nemesis 'n goddelike dimensie aan die gedig verleen en die verskillende doelstellings universaliseer.

28. Quinn (1973:239) lewer die volgende kommentaar oor vv. 18-21: "Catullus does not formally propose a second meeting. Instead he strikes a mock-tragic note, and threatens Calvus with divine punishment if he meets Catullus's request with arrogant refusal. The bantering tone is in selfprotection - Calvus may not want him as a close friend. At the same time the poema is intended as a demonstration that Catullus deserves Calvus's friendship". 
ervaring van die gedeelde kreatiewe proses vergelykbaar is met die erns en intensiteit van 'n seksuele ervaring binne 'n liefdesverhouding. Soos in 'n seksuele ervaring vind daar ' $n$ stelselmatige opbou van gevoel plaas sodat Catullus aan die einde van hul dag saam so aangevuur is dat hy glad nie kan slaap of eet nie - tipiese simptome van verliefdheid. Dit is uit verlange na die gevoel wat ontstaan gedurende die gedeelde proses van dig waar Calvus betrokke was, dat die kreatiewe proses by Catullus gestimuleer word en die skryf van werklike poësie (in hierdie geval c. 50) realiseer. Catullus maak gebruik van sy nuutgevonde vriendskap met Calvus om as verskoning te dien vir die skryf van 'n gedig. Die spanninge rondom 'n verhouding met Calvus word dan as 'n metafoor vir die kreatiewe proses gebruik.

Soos by Catullus, word die ervaring van die kreatiewe proses ook in moderne gedigte verder ontwikkel, waar die kreatiewe proses van skryf in die vorm van 'n persona uitgebeeld word. In die bespreking word die gedig "die skryfproses, as sonnet" van Antjie Krog as voorbeeld van 'n moderne Afrikaanse gedig bestudeer, waar sy die man as metafoor vir die proses van kreatiwiteit gebruik. Soos by Catullus maak Krog gebruik van erotiese beelde vir die uitbeelding van die tipe verhouding wat tussen die kunstenaar en die kreatiewe proses waargeneem word.

\section{die skryfproses, as sonnet}

hoe bang het ek geword om poëties baldadig te dink, om my geliefde rymloos en vormloos te laat uitrank hoe sku het ek geword om in lote onbevange vers sy penis onverantwoordelik ysterklaar by die naam te noem

die krimp en los van sy balle by daglig waar te neem die sagte kurk van sy tepels tot harde stukkies bas om brutale stuifmeel oor blare te vlek en argloos sy anus aan my pen te laat bot

maar totaal geïnhibeer deur laboratorium toetse en handleidings bedink ek elke derde dag netjiese stellasies vers, noukeurig en dimensioneel opgelei, verrassend berym en kosmies met titels bemes

en uiteindelik: ryp gekwartryn, onpersoonlik met kenners oor gekweel, word die hele seksdaad nou 'n slim-slim slimmer ritueel.

\section{Antjie Krog: Otters in Bronslaai (1981:35)}

Hierdie gedig se titel verklap reeds dat "die skryfproses", oftewel die proses van kreatiwiteit, "as sonnet" bespreek word. Die uiterlike bou van die gedig volg wel die Italiaanse sonnet ${ }^{29}$ in struktuur waar die eerste twee kwatryne 'n oktaaf vorm, gevolg deur 'n sekstet bestaande uit twee tersines. Wanneer ons egter die rymskema beskou, breek die gedig weg van die gebruiklike omarmende rym (abba/abba) in die oktaaf en kruisrym (cdc/dcd) in die sekstet. Daar is slegs ' $\mathrm{n}$ enkele voorbeeld van gewysigde binnerym ${ }^{30}$ in die laaste twee versreëls

29. 'n Sonnet is 'n gedig met 'n vaste vorm, waarvan een soort (Italiaanse sonnet) uit vier strofes bestaan, die eerste twee (die oktaaf) met vier reëls elk (kwatryne), en die volgende twee (sekstet) met drie reëls elk (tersines) (Odendal, 1983:1031).

30. "Binnerym" is die term wat gebruik word wanneer "die rymende lettergrepe binne die versreël herhaal word" (De Klerk, 1987:581). In hierdie geval rym die woord "gekweel" wat binne versreël 13 voorkom met "ritueel" wat aan die einde van die veertiende versreël staan. 
("gekweel" v. 13 en "ritueel" v. 14) te vind. As vrye vers bevestig die gedig 'n behoefte om weg te breek van wat normaalweg beskou word as "tipies sonnet". Hierdie behoefte figureer dwarsdeur die gedig, soos 'n soort opstandigheid, waar sekere tipiese eienskappe van die sonnet ondermyn word, terwyl ander wel gevolg word.

Ook bestaan die Italiaanse sonnet meestal uit veertien vyfvoetige jambiese versreëls, maar vind ons in hierdie gedig dat die metrum reeds in die eerste versreël afwyk vanaf die jambiese ("hoe báng het ék gewórd") na die anapestiese versvoet ("om poéties baldádig te dínk"). 'n Verdere voorbeeld van metrum-verandering word in die derde versreël aangetref: "hoe skú het ék gewórd" bestaan uit drie jambiese versvoete, wat in dieselfde versreël oorgaan na 'n anapestiese versvoet ("om in lóte") en eindig met drie trogeïse versvoete ("ónbevánge vérs"). Saam met die weglaat van 'n rymskema en gebrek aan hoofletters en leestekens (wat gewoonlik die wending in die sonnet aandui), vorm die onwillekeurige ritme die mees ooglopende afwyking van die normale bouvorm van die Italiaanse sonnet.

Die gedig se innerlike bou stem ooreen met dié van die tipiese Italiaanse sonnet, sover daar 'n wending plaasvind in die begin van die sekstet, aangedui deur die woord "maar". Hierdie wending (of "volta") is die punt waar die toepassing, verklaring of verdieping intree, en dit vind gewoonlik aan die begin van die sekstet plaas. So ook is dit in hierdie gedig die geval, waar "maar" (v. 9) die wending begin, en "en uiteindelik" (v. 12) 'n verdere verdieping in die laaste tersiene inlei. Eienaardig genoeg is die oktaaf meer liries en die sekstet meer verhalend van aard - die omgekeerde van die normale patroon.

Soos pas uitgewys is hierdie gedig, wat uiterlike en innerlike bou betref, nie die gewone Italiaanse sonnet nie. Die titel bevestig dat die skrywer bewustelik die sonnet as boumateriaal gekies het, maar die "reëls" word op verskeie maniere verontagsaam. Die digter se keuse van die sonnet as bouvorm is baie belangrik vir die betekenis van die gedig, aangesien die strengheid van vorm (van die sonnet) gebruik word om beide uiterlik en innerlik teen te rebelleer. Sy verduidelik in die gedig dat sy "bang" (v. 1) geword het "om poëties baldadig te dink" (v. 1), om dus sonder vorm en rym (v. 2) die proses van kreatiwiteit ("my geliefde" v. 2) vrye teuels te gee ("te laat uitrank" v. 2; "in lote onbevange vers" v. 3).

Haar daaropvolgende beskrywing van die "geliefde" (v. 2) is suiwer manlik ("sy penis" v. 4; "sy balle" v. 5; "sy tepels" v. 6; "sy anus" v. 8) en eroties ("brutale stuifmeel" v. 7). Ons het hier dus te doen met 'n unieke beeld van die man as metafoor vir die proses van kreatiwiteit.

In die eerste tersine verduidelik sy hoe die proses van kreatiwiteit van spontaneïteit ontneem word ("geïnhibeer" v. 9) - hoe dit 'n wetenskaplike ("laboratoriumtoetse en handleidings" v. 9), suiwer intellektuele ("bedink" v. 10) proses geword het waar sy volgens 'n sekere resep ("elke derde nag" v. 10) poësie produseer. Die proses van kreatiwiteit word 'n opleidingsproses ("noukeurig en dimensioneel opgelei" v. 10-11); ook is dit pretensieus ("verrassend berym en kosmies met titels bemes" v. 11).

Die tweede tersiene dien as die finale opsomming van die situasie: "en uiteindelik" (v. 12), waarna die onbetrokkenheid ("onpersoonlik", v. 12) van die digter tydens die proses van skryf vergelyk word met dié van 'n persoon wat die seksdaad (v. 13) ervaar as 'n intellektuele ritueel ("slim-slim slimmer ritueel", v. 14). Die proses van kreatiwiteit word dus as 'n seksuele ervaring beskryf, ${ }^{31}$ waar die skrywer sensories afgestomp raak vir die ervaring van skryf, soos wat geliefdes soms afgestomp raak vir die ervaring van die liefdesdaad.

31. Soos by implikasie in c. 50 en 38 waar Catullus onderskeidelik gestimuleer word en stimulering benodig deur die kreatiewe proses. 
Deur die bespreking van beide Catullus en Krog se gebruik van 'n persona as metafoor vir die proses van kreatiwiteit, word die leser opnuut bewus van die tydloosheid verbonde aan die kunstenaar se ervaring van die kreatiewe proses.

\section{BIBLIOGRAFIE}

Arkins, B 1982. Sexuality in Catullus. Hildesheim: Olms.

Burgess, D L 1986. Catullus C. 50; The Exchange of Poetry. AJP 108: 576-586.

Clack, J 1976. Otium tibi Molestum Est. CB 52: 50-53.

Copley, F O 1949. Emotional Conflict and its Significance in the Lesbia-poems of Catullus. AJP 70: 22-40.

De Klerk, P F, Esterhuizen, B J, Hammann, H J R \& Neethling, E L 1987. Afrikaans my Taal 9/10. Kaapstad: Maskew Miller Longman.

Ellis, R A 1889. Commentary on Catullus. Oxford: Clarendon Press.

Ferguson, J 1985. Catullus. Birmingham: Coronado Press.

Fitzgerald, W 1995. Catullan Provocations: Lyric Poetry and the Drama of Position. California: University of California Press.

Fordyce, C J 1961. Catullus. Oxford: Clarendon Press.

Fraenkel, E 1956. Catulls Trostgedicht für Calvus. WS 69: 278-288.

Havelock, E A 1939. The Lyric Genius of Catullus. Oxford: Basil Blackwell.

Krog, A 1981. Otters in Bronslaai. Kaapstad: Human \& Rousseau.

Laidlaw, W A 1948. Otium. G\&R 15: 42-52.

Lee, G 1990. The Poems of Catullus. Oxford: Clarendon Press.

Macleod, C W 1973. Parody and Personalities in Catullus. CQ 23: 294-303.

Martin, C 1990. The Poems of Catullus. Baltimore and London: The John Hopkins University Press.

Merrill, E T 1951. Catullus. Cambridge: Harvard University Press.

Newman, J K 1990. Roman Catullus and the Modification of the Alexandrian Sensibility. Hildesheim: Weidmann.

Odendal, F F, Schoonees, P C, Swanepoel, C J, Du Toit, S J \& Booysen, C M 1983. HAT: Verklarende Woordeboek van die Afrikaanse Taal. Johannesburg: Perskor-Uitgewery.

Quinn, K 1959. The Catullan Revolution. Melbourne: Melbourne University Press.

Quinn, K 1972. Catullus: An Interpretation. London: B T Batsford.

Quinn, K 1973. Catullus: The Poems. London: Macmillan.

Rubino, C A 1975. The Erotic World of Catullus. CW 68: 289-298.

Scott, W C 1969. Catullus and Calvus. CP 64: 169-173.

Segal, C 1970. Catullan Otiosi: The Lover and the Poet. G\&R 17: 25-31.

Wheeler, A L 1934. Catullus and the Traditions of Ancient Poetry. Berkeley: University of California Press.

Williams, G 1980. Figures of Thought in Roman Poetry. New Haven: Yale University Press.

Williams, M F 1988. Catullus 50 and the Language of Friendship. Latomus 47: 69-73. 